\title{
Penerapan Media Bimbingan Konseling untuk Meningkatkan Keterampilan Guru BK dalam Memberikan Layanan Pendidikan Seks terhadap Peserta Didik
}

\author{
Ni Komang Sri Yuliastini ${ }^{*}$, I Dewa Ayu Eka Purba Dharma Tari², Putu Agus Semara Putra \\ Giri $^{3}$, Made Wery Dartiningsih ${ }^{4}$
}

1,2,3,4 Program Studi Bimbingan dan Konseling FIP IKIP PGRI Bali

\section{A R T I C L E I N F O}

Article history:

Received in revised form

Accepted 30 April 2020

Available online 28 May 2020

Kata Kunci:

Media BK, Guru BK,

Pendidikan Seks

Keywords

BK media, BK teachers, sex education
Received 10 February 2020 25 March 2020

\section{A B S T R A K}

Tujuan pengabdian ini adalah peningkatan keterampilan Guru Bimbingan dan Konseling dalam membuat materi dan media Bimbingan dan Konseling pada SMP Swastika Kapal, Kab. Badung. Media bimbingan dan konseling ialah segala sesuatu yang dapat digunakan untuk menyampaiakan pesan bimbingan dan konselinya yang merangsang pikiran, perasaan, perhatian, keinginan konseli untuk memahami diri dan mengambil keputusan atau masalah yang sedang dihadapi. Sasaran kegiatan pengabdian masyarakat adalah Guru Bimbingan Konseling SMP Swastika Kapal. Kegiatan diharapkan memberikan kontribusi kepada Sekolah, guru BK serta peserta didik, dimana dari pihak sekolah menambah perangkat pembelajaran berupa media BK, guru BK memiliki pengetahuan dan kreativitas untuk menuangkan materi BK salah satunya pendidikan seks dan bagi peserta didik memberikan wawasan mengenai pendidikan seks serta mencegah perilaku yang menyimpang bagi remaja. Menghasilkan produk media BK yang interaktif sesuai tema yaitu "Pendidikan Seks pada Peserta Didik" serta hasil post test peserta didik yang tinggi mengenai pemahaman paparan materi yang disampaikan oleh guru BK merupakan keberhasilan dalam pelatihan ini. Penerapan Media BK diharapkan memiliki ragam tema dan ide yang kreatif sehingga program BK di Sekolah berjalan secara efektif.

\section{A B S T R A C T}

The purpose of this service is to improve the skills of Guidance and Counseling Teachers in making material and media Guidance and Counseling in Ship Swastika Middle School, Kab. Badung Guidance and counseling media are all things that can be used to deliver guidance and counseling messages that stimulate the thoughts, feelings, attention, counselee's desire to understand themselves and make decisions or problems being faced. The target of community service activities is the Swastika Ship Junior High School Counseling Guidance Teacher. The activity is expected to contribute to schools, counseling teachers and students, where the school will add learning tools in the form of counseling media, counseling teachers have the knowledge and creativity to write counseling material, one of them is sex education and students provide insight into sex education and prevent behavior which is distorted for adolescents. Producing interactive BK media products according to the theme "Sex Education for Students" as well as high student post-test results regarding understanding of material exposure delivered by BK teachers was a success in this training. The application of BK Media is expected to have a variety of creative themes and ideas so that the BK program in Schools runs effectively.

Copyright (C) Universitas Pendidikan Ganesha. All rights reserved.

\footnotetext{
* Corresponding author.

E-mail addresses: anna.triwijayati@machung.ac.id (Ni Komang Sri Yuliastini1)
} 


\section{Pendahuluan}

sistem pendidikan di Indonesia dewasa ini tampak ada kesenjangan antara kenginan dan realita. Secara makro dapat dilihat dalam aspek pengelolaan, peran pemerintah dan masyarakat, kurikulum atau materi ajar, pendekatan dan metodologi pembelajaran, sumber daya manusia, lingkungan kampus atau sekolah, dana, dan akreditasi. Kesenjangan dalam sistem pendidikan tersebut disebabkan karena faktor politik, ekonomi, sosial-budaya dan sebagainya yang selalu berubah sesuai dengan perubahan dan perkembangan zaman (Munirah, 2015). Menurut Omeri (2015) Pendidikan merupakan bagian penting dari kehidupan manusia yang tak pernah ditinggalkan.Sebagai sebuah proses, ada dua hal asumsi yang berbeda mengenai pendidikan dalam kehidupan manusia. Pertama, bisa dianggap sebagai sebuah proses yang terjadi secara tidak disengaja atau berjalan secara alamiah. Pendidikan bukanlah proses yang diorganisasi secara teratur, terencana, dan mengunakan metode-metode yang dipelajari serta berdasarkan aturan-aturan yang telah disepakati mekanisme penyelenggaraannya oleh suatu komunitas masyarakat (Negara), melainkan lebih merupakan bagian dari kehiupan yang memang telah berjalan sejak manusia itu ada. Pendidikan adalah media, aktifitas untuk mencerdaskan bangsa. Dalam prosesnya guru merupakan ujung tombak dalam peningkatan kualitas pendidikan sehingga semakin tinggi kualitas guru maka kualitas pendidikan meningkat dengan demikian idealnya mampu menjawab semua permasalahan yang dimiliki baik yang berupa material maupun spiritual. Menurut Afrianto (2011) Kebutuhan pendidikan merupakan salah satu bagian terpenting dari kehidupan manusia, dengan pendidikan yang lebih tinggi diharapkan akan manghasilkan manusia-manusia yang lebih berkualitas.

Sejalan dengan hal diatas persoalan pendidikan di Indonesia sebagai berikut. Pertama, kesempatan mendapatkan pendidikan masih tetap terbatas. Kedua, kebijakan pendidikan nasional sentralistik dan menekankan uniformitas (keseragaman) yang mengakibatkan beban kurikulum serba seragam dan overloaded. Ketiga, pendanaan yang masih belum memadai karena pemerintah belum menjadikan pendidikan sebagai prioritas utama dalam pembangunan Indonesia, keempat, akuntabilitas yang berkaitan dengan pengembangan dan pemeliharaan sistem dan kualitas pendidikan yang masih timpang. Kelima, profesionalisme guru dan tenaga kependidikan yang masih belum memadai, keenam, relevansi yang masih timpang dengan kebutuhan masyarakat dunia kerja [2]. Agar pendidikan dapat berhasil sesuai dengan tujuan diperlukan berbagai sarana atau sumberdaya seperti bangunan sekolah, buku/materi pelajaran, guru dan sarana pendukung lainnya [3].

Permendikbud Nomor 111 Tahun 2014 pasal 4 ayat (4) tentang Pemenuhan Beban Kerja Guru, Kepala Sekolah dan Pengawas Sekolah dijelaskan bahwa: pengakuan jam kerja konselor atau guru bimbingan dan konseling diperhitungkan dengan rasio 1 : 150 ekuivalen dengan jam kerja 24 jam [4]. Beban kerja bagi guru BK yang padat untuk melaksanakan program yang telah direncanakan baik program harian, program mingguan, program bulanan, program semesteran serta program tahunan. Beberapa sekolah menerapkan guru BK untuk masuk kelas untuk melaksanakan program yang telah dirancang. Namun sebagian besar sekolah tidak memberikan jam masuk kelas sedangkan program BK yang bertujuan untuk mengoptimalisasi potensi siswa memiliki materi yang sangat padat sesuai dengan program yang dirancang. Sarana prasarana yang mendukung menjadi unsur penting dalam pelaksanaan program BK di sekolah.

Menurut Kamaluddin (2011) Bimbingan dan konseling merupakan upaya proaktif dan sistematik dalam memfasilitasi individu mencapai tingkat perkembangan yang optimal, pengembangan perilaku yang efektif, pengembangan lingkungan, dan peningkatan fungsi atau manfaat individu dalam lingkungannya. Semua perubahan perilaku tersebut merupakan proses perkembangan individu, yakni proses interaksi antara individu dengan lingkungan melalui interaksi yang sehat dan produktif. Membuat menarik Bimbingan dan Konseling (BK) memang bukan saja dari segi kualitas konselornya saja, ruang BK yang nyaman juga merupakan daya tarik tersendiri, namun tidak sedikit dari ruang BK yang memang seadanya bahkan hampir tidak ada ruang BK [5]. "Terbukti, ruang BK dengan segala fasilitas yang seharusnya ada belum mendapat perhatian dari sekolah. Tempat/ruang BK yang kecil dan dibelakang (kurang strategis) dengan fasilitas yang cukup memprihatinkan. Dengan kondisi fisik seperti ini tentunya BK tidak akan dihampiri siswa/orang tua siswa yang berkeinginan sendiri berkonsultasi atau yang lainnya karena layanan BK tidak mempunyai daya tarik sendiri. Apalagi masih ada konsepsi ketika guru BK bertindak sebagai polisi sekolah, bukan hanya murid, guru-guru, bahkan orang tuapun masih memiliki pandangan bahwa ruang BK adalah tempat anak bermasalah. 


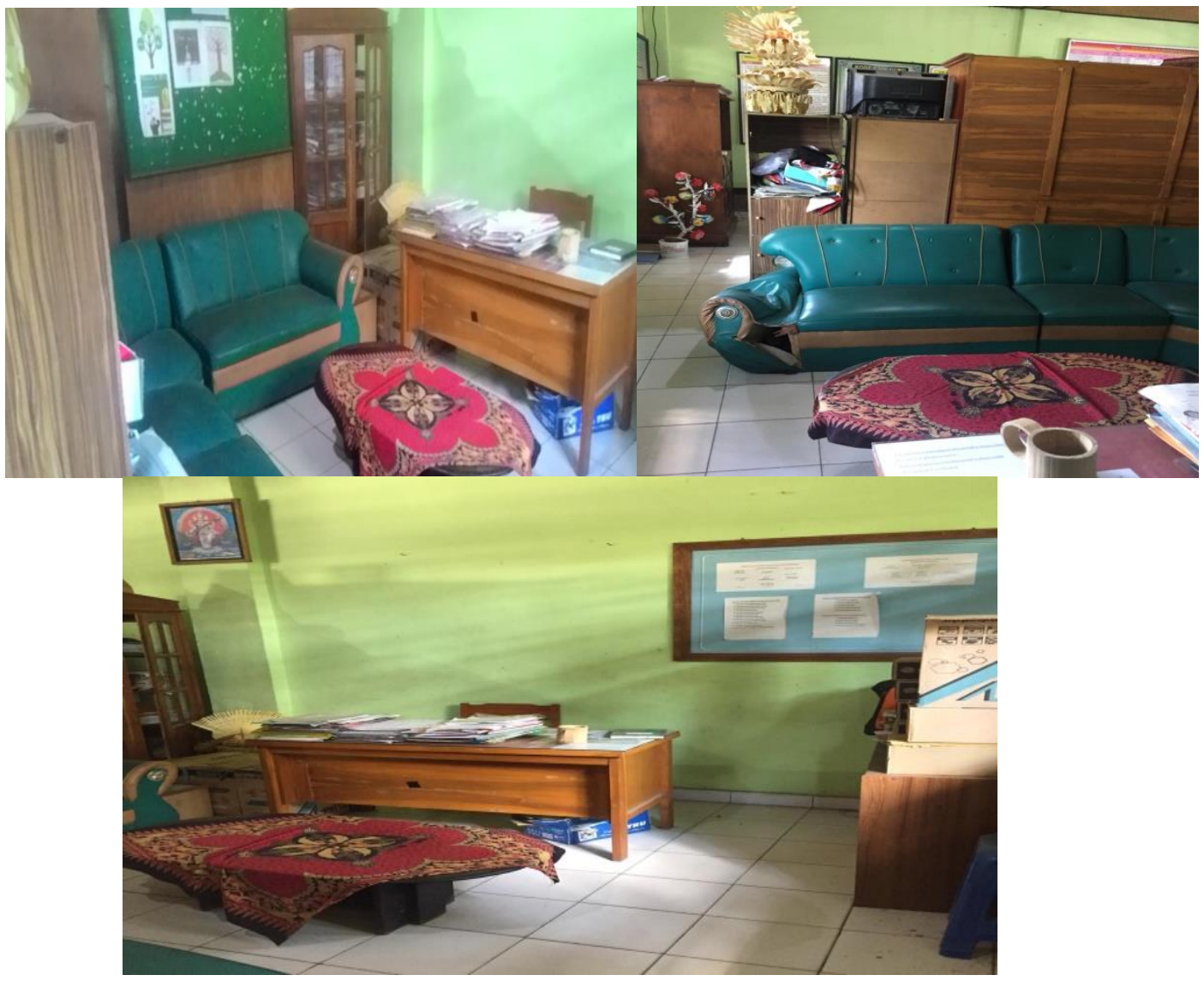

Gambar 1. Ruang Bimbingan dan Konseling SMP Swastika Kapal

Bimbingan konseling memiliki tujuan secara prefentif (pencegahan) dan secara kuratif ( pengentasan). Tindakan pencegahan agar siswa tidak terjerumus kepada hal-hal negatif dapat dilakukan dengan beberapa cara. Perilaku siswa dengan segala hal yang berbau modern semakin sulit dipantau perkembangannya. Perilaku anak yang cenderung mengarah kebebasan dalam pergaulan perlu di antisipasi dengan pendidikan moral sesuai usia mereka. Pergaulan bebas yang terjadi pun mendorong mereka melakukan hal yang negatif. Ada sekitar 40-60 persen remaja SMP Indonesia yang telah melakukan hubungan seks, perilaku ini pun mendorong jumlah aborsi yang tidak aman meningkat. Per tahun, 2,3 juta prosedur aborsi yang dilakukan di Indonesia. Sebagian dari 2,3 juta tindak aborsi tersebut dilakukan oleh secara tidak aman, seperti dukun beranak. Yang cukup memperihatinkan, dalam beberapa tahun kedepan jumlah tersebut dapat meningkat hingga 3 juta. Maraknya tindak aborsi ini turut memberi sumbangsih pada tingginya angka kematian ibu [6]. Padahal, dengan jumlah dokter dan bidan yang cukup banyak di Indonesia, angka kematian ibu bisa ditekan. Tak henti disitu, kurangnya pendidikan seks yang tepat sejak dini juga membuat angka penyebaran HIV-AIDS di Indonesia cenderung tinggi. Perilaku nyata yang terjadi akibat pergaulan bebas di kalangan remaja semakin memprihatinkan. Seperti yang tercatat di detiknews pada hari Kamis, 09 Maret 2017, terdapat pelajar di Surabaya yang mesum di kamar pas. Bahkan ada pula pelajar di Bekasi yang secara patungan menyewa kamar-kamar kos untuk kemudian dipergunakan berbuat mesum [7]. Hasil serupa yang menunjukan perilaku seks bebas di kalangan pelajar adalah dari survey yang melibatkan 4.500 responden, ternyata 62,7\% siswa SMP mengaku sudah pernah berhubungan intim layaknya suami istri. Menurut Dokter dari BKOW Gorontalo, Sulianti Otto, mengungkakan penyebab remaja usia SMP saat ini bertindak di luar kepatutan karena mereka pernah dan aktif menonton materi pornografi. Hal ini dikuatkan dengan hasil survei yang dilakukan BKKBN pada akhir 2015 menyatakan, 73\% remaja di beberapa kota besar di Indonesia melakukan seks pranikah [8]. Jika pendidikan seks tidak diberikan sejak dini, bukan tidak mungkin jika nantinya Indonesia akan menggeser Thailand dari posisi HIV-AIDS terbesar se Asia Pasifik. Sayangnya banyak orang tua yang merasa tabu atau tidak tahu bagaimana memberikan pendidikan seks yang tepat pada anak. Ketiadaan pendidikan seks yang tepat pada anak ini menimbulkan rasa penasaran yang mereka jawab dengan cara yang tidak sesuai norma. Melalui pendidikan seks, anak akan lebih mengenali fungsi tubuhnya, menghindari apa yang seharusnya tidak dilakukan serta memahami konsekuensi dari tiap perbuatannya 
[9]. Dengan begitu, anak akan dapat menjauhkan diri dari penyimbangan seksual dan menghindarkan diri dari bahaya pelecehan seksual. Pendidikan seks yang benar bisa menyelamatkan anak dari pelecehan dan penyimpangan seksual. Menjawab permasalahan tersebut diatas, solusi yang dapat diberikan adalah dengan membuat media bimbingan konseling yang dibuat secara kreatif agar menarik minat siswa untuk melihat.

Bimbingan dan konseling memiliki andil yang cukup luas dalam hal ini. Konselor sekolah memiliki peran yang strategis untuk mengatasi maraknya perilaku seks bebas di kalangan pelajar. Dengan memanfaatkan kondisi yang serba digital ini, pemberian layanan bimbingan dan konseling tidak harus melalui tatap muka, ceramah, dan konvensional. Konselor dapat melakukan kegiatan layanan bimbingan dan konseling dengan pemanfaatan media bimbingan konseling. Tidak menutup kemungkinan pelaksanaan layanan pendidikan seks untuk siswa juga melalui pemanfaatan media bimbingan konseling yang terletak di lokasi-lokasi strategis siswa pada saat disekolah serta pemanfaatan media elektronik power point pun dapat dilakukan.

Pendidikan seks meliputi bagaimana membuat orang tua siswa memiliki keterampilan komunikasi tentang seksualitas secara tepat dengan anaknya, informasi kontrasepsi, pencegahan kehamilan, serta perawatan kesehatan reproduksi [10]. Dalam hal ini guru BK dapat memberikan materi yang cukup luas dan sesuai dengan tahap perkembangan siswanya.

Pendidikan seks adalah salah satu cara untuk mengurangi atau mencegah penyalahgunaan seks, khususnya untuk mencegah dampak negatif, seperti kehamilan yang tidak direncanakan, penyakit menular seksual, depresi dan perasaan berdosa. Di dalam pendidikan seks ini bukan hanya perihal seks saja yang dapat dijelaskan [11]. Lebih luas lagi adalah bagimana nilai-nilai bisa ditransformasikan dari pendidik ke pada siswa. Materi tentang seks tidak disampaikan secara vulgar akan tetapi diberikan secara kontekstual. Pendidik memperhatikan norma-norma yang berlaku dalam masyarakat, sehingga apa yang boleh dan tidak boleh dilakukan dan bagaimana cara melakukannya tanpa melanggar aturan yang berlaku menjadi bagian yang tidak terpisahkan dalam pelaksanaan pendidikan seks [12].

Pendidikan seks sangat diperlukan dalam upaya menangani perilaku seks bebas di kalangan pelajar. Dengan adanya pendidikan seks, siswa akan mengetahui dan memahami bahaya-bahaya yang mengiringi perilaku tersebut. Diharapkan apabila mereka mengetahui dan memahami apa saja yang akan mereka hadapi apabila melakukan seks bebas, para remaja akan lebih berhati-hati memutuskan tindakan yang dilakukan. Menjauhi segala aktivitas yang menuju pada pergaulan bebas. Hal ini sesuai dengan pendapat Nadeak (1991) bahwa jika pendidikan seks tidak disampaikan maka anak tidak akan memahami fungsi seks dalam tubuh mereka [13]. Bahayanya adalah ketika mereka mencari tahu dari sumber yang tidak tepat, dan keterangan yang mereka peroleh menyesatkan, maka dimungkinkan akan berdampak kurang sehat bagi dirinya.

Media bimbingan dan konseling ialah segala sesuatu yang dapat digunakan untuk menyampaiakan pesan bimbingan dan konselinya yang merangsang pikiran, perasaan, perhatian, keinginan konseli untuk memahami diri dan mengambil keputusan atau masalah yang sedang dihadapi [14]. Pada dasarnya media bimbingan dan konseling tidak terbatas hanya berfungsi sebagai perantara sebuah pesan, melainkan memiliki makna yang lebih luas adalah segala alat bantu yang dapat digunakan dalam melaksanakan progam BK. Media BK terdiri atas dua unsur penting yaitu (1) unsur peralatan/ perangkat keras dan (2) unsur pesan yang dibawanya. Dengan demikian, media BK yang terpenting bukan peralatannya melainkan pesan atau informasi yang dibawakan oleh media tersebut [15].

Tim pengabdian kegiatan dari Program Studi Bimbingan dan Konseling memberikan intervensi dalam rangka memenuhi kebutuhan akan tugas pekembangan remaja dalam aspek pengetahuan pendidikan seks. Melalui sebuah program kegiatan pendampingan kepada guru BK di sekolah untuk memberikan layanan pendidikan seks dengan sistem pendampingan penyusunan media bimbingan dan konseling. Bentuk pendidikan seks melalui pendampingan penyusunan media bimbingan dan konseling yang dimaksudkan akan memasukan materi-materi yang berkaitan dengan definisi seks, kesehatan reproduksi, aborsi, dan penyakit menular seksual.

\section{Metode}

Pendampingan dilaksanakan dengan langkah-langkah sebagai berikut:

1. Melakukan sosialisasi tentang gambaran umum kegiatan pengabdian kepada masyarakat ini dilakukan kepada kepala sekolah dan guru BK. Tim pengabdian memberikan sosialisasi tentang apa itu media bimbingan dan konseling, jenis-jenis media bk dan bagaimana hubungan antar keduanya serta bagaimana pemanfaatan dalam layanan BK khususnya untuk pendidikan seks terhadap siswa. 
2. Berkoordinasi dengan pihak SMP Swastika Kapal (khususnya Guru BK) berkaitan dengan kegiatan pendampingan. Terutama hal-hal yang berhubungan dengan tempat, sarana prasarana yang diperlukan untuk kegiatan pelatihan, serta jadwal pelaksanaan. Peserta pelatihan adalah seluruh Guru BK dan operator sekolah. Adapun subjek atau target sasaran dalam kegiatan pendampingan ini adalah seluruh siswa di SMP Swastika Kapal sejumlah 86 siswa. Pelatihan dijadwalkan sebanyak empat kali pertemuan, dengan durasi setiap pertemuan selama 1 jam.

3. Menyebar angket pre tes kepada seluruh subjek atau sasaran pengabdian kepada masyarakat, sejumlah 86 siswa.

4. Pelaksanaan pendampingan untuk membuat media bk dengan tema yang berbeda-beda, antara lain: (1) Arti dan pentingnya pendidikan seks, (2) Say No to Free Sex, (3) Aborsi dan penyakit menular seks sebagai dampak seksbebas dan (4) Kesehatan reproduksi.

5. Menyebar angket post tes untuk seluruh siswa di SMP Swastika Kapal, sejumlah 86 siswa

\section{Hasil dan Pembahasan}

Pada bagian ini dipaparkan beberapa hal yang terkait dengan pelaksanaan program. Meliputi hasil yang dicapai dan pembahasan pelaksanaan pengabdian masyarakat. Adapun sebaran Tema Abdimas adalah sebagai berikut :

Tabel 1. Sebaran Tema Abdimas

\begin{tabular}{|c|c|c|c|c|c|c|}
\hline No & Tema & Waktu & $\begin{array}{l}\text { Produk } \\
\text { material }\end{array}$ & Narasumber & Lokasi & Peserta \\
\hline 1 & $\begin{array}{l}\text { Arti dan } \\
\text { Pentingnya } \\
\text { Pendidikan } \\
\text { Seks }\end{array}$ & $\begin{array}{l}\text { Pertemuan } \\
\text { Ke } 1 \\
\end{array}$ & PPT & Penyuluh & $\begin{array}{ll}\text { SMP } & \text { Swastika } \\
\text { Kapal } & \\
& \end{array}$ & $\begin{array}{l}\text { Guru BK \& } \\
\text { Operator } \\
\text { Sekolah }\end{array}$ \\
\hline 2 & $\begin{array}{l}\text { Aborsi dan } \\
\text { Penyakit } \\
\text { menular } \\
\text { seks } \\
\text { Sebagai } \\
\text { dampak } \\
\text { seks } \\
\text { Bebas }\end{array}$ & $\begin{array}{l}\text { Pertemuan } \\
\text { Ke } 2 \\
\\
\end{array}$ & PPT & Penyuluh & $\begin{array}{l}\text { SMP } \\
\text { Swastika } \\
\text { Kapal }\end{array}$ & $\begin{array}{l}\text { Guru BK \& } \\
\text { Operator } \\
\text { Sekolah }\end{array}$ \\
\hline 3 & $\begin{array}{l}\text { Say No to } \\
\text { Free Sex }\end{array}$ & $\begin{array}{l}\text { Pertemuan } \\
\text { Ke } 3\end{array}$ & $\begin{array}{l}\text { Papan } \\
\text { Bimbingan }\end{array}$ & Penyuluh & $\begin{array}{l}\text { SMP } \\
\text { Swastika } \\
\text { Kapal }\end{array}$ & Guru BK \& \\
\hline 4 & $\begin{array}{l}\text { Kesehatan } \\
\text { Reproduksi }\end{array}$ & $\begin{array}{l}\text { Pertemuan } \\
\text { Ke } 4\end{array}$ & $\begin{array}{l}\text { Papan } \\
\text { Bimbingan }\end{array}$ & Penyuluh & $\begin{array}{l}\text { SMP } \\
\text { Swastika Kapal }\end{array}$ & $\begin{array}{l}\text { Siswa SMK } \\
\text { St. }\end{array}$ \\
\hline 5 & $\begin{array}{l}\text { Kesehatan } \\
\text { Reproduksi }\end{array}$ & $\begin{array}{l}\text { Pertemuan } \\
\text { Ke } 5\end{array}$ & $\begin{array}{l}\text { Papan } \\
\text { Bimbingan }\end{array}$ & Penyuluh & $\begin{array}{l}\text { SMP } \\
\text { Swastika Kapal }\end{array}$ & $\begin{array}{l}\text { Siswa SMP } \\
\text { Swastika Kapal }\end{array}$ \\
\hline 6 & $\begin{array}{l}\text { Kesan } \\
\text { Pesan } \\
\text { Siswa } \\
\end{array}$ & $\begin{array}{l}\text { Pertemuan Ke } \\
6\end{array}$ & Post It & Penyuluh & Swastika & $\begin{array}{l}\text { Siswa } \\
\text { Swastika Kapal }\end{array}$ \\
\hline
\end{tabular}

Pelaksanaan salah satu Tri Dharma yaitu pengabdian kepada masyarakat, dosen IKIP PGRI Bali dinaungi oleh LP2M. Dukungan yang diberikan oleh LP2M IKIP PGRI Bali dalam pelaksanaan kegiatan pengabdian kepada masyarakat adalah dengan memberikan kesempatan kepada seluruh dosen untuk mengabdikan diri ke masyarakat sesuai dengan rumpun ilmu masing-masing dosen. Dukungan lain yang tidak kalah penting adalah kegiatan pengabdian, pemberian surat tugas, dan informasi lain yang berkaitan dengan kegiatan pengabdian.

Pelaksanaan program ini melibatkan 3 (tiga) orang Guru BK, 2 (dua) operator dan 2 (dua) orang mahasiswa. Adapun keterlibatan mahasiswa untuk membantu tim dalam pelaksanaan kegiatan 
berlangsung. Kegiatan dilaksanakan di ruang rapat SMP Swastika Kapal guna mendapatkan ruangan yang cukup luas terkait dengan kegiatan pembuatan media BK sebagai hasil dari kegiatan pengabdian.

Kegiatan berlangung secara interaktif sesuai dengan jadwal yang direncanakan. Target capaian yaitu keterampilan guru BK dan operator berupa :

1. Pemahaman mengenai teori pendidikan seks pada remaja yang belum tertera dalam program pelaksaan BK di Sekolah

2. Pemanfaatan media PPT dan pembuatan media BK berupa papan bimbingan sebagai prakarya yang akan dipajang untuk bahan pembelajaran peserta didik diluar jam pelajaran.

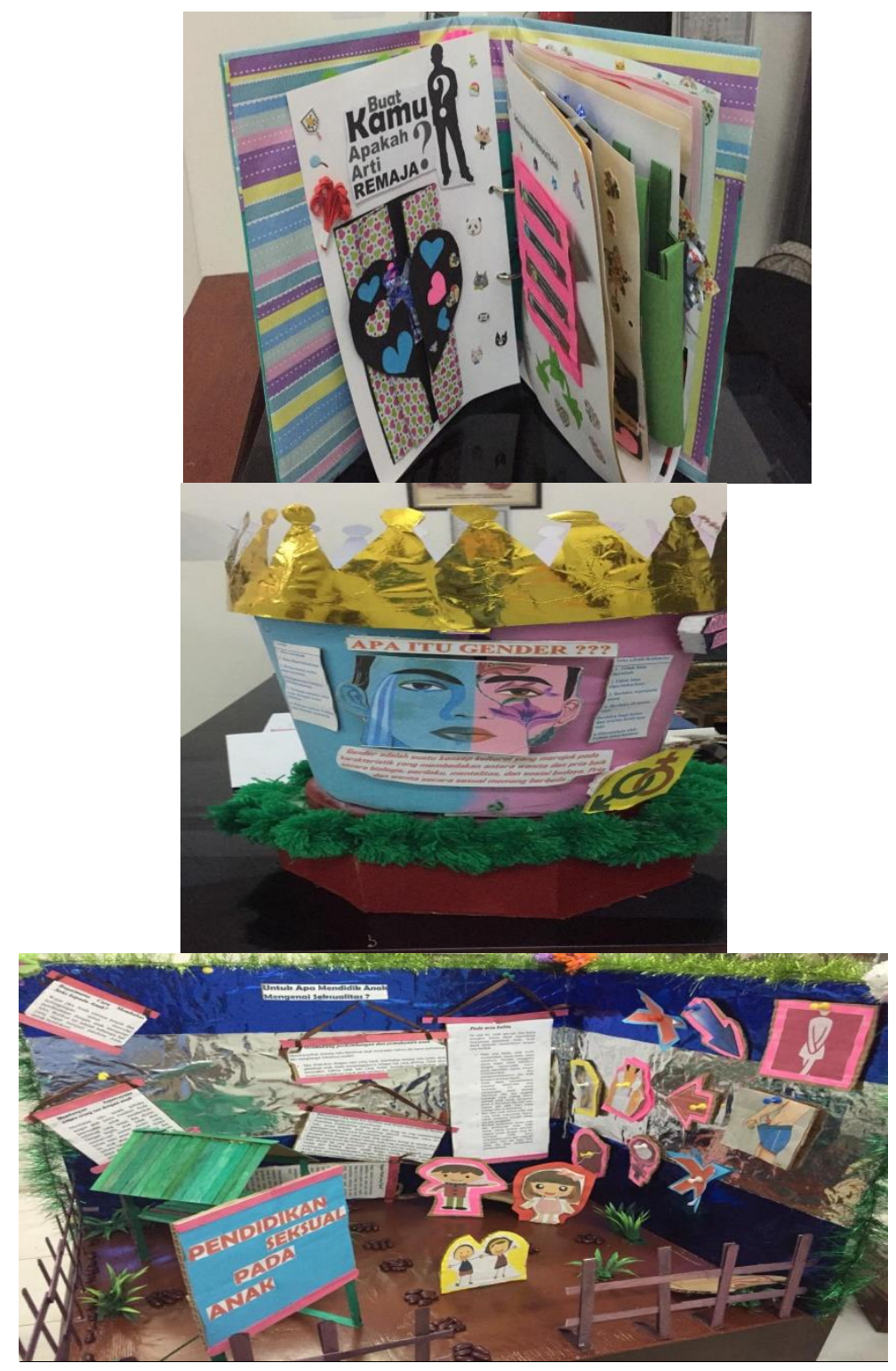

Gambar 2. Hasil Media BK

Berdasarkan diskusi yang dilaksanakan setelah kegiatan pendalaman dan pelatihan media BK terlihat bahwa para guru BK memahami akan pentingnya pendidikan seksual pada peserta didik dengan pemanfaatan media BK. Hal ini disebabkan bahwa jam masuk kelas BK sangat minim di sekolah. Mediamedia yang dihasilkan dalam bentuk media keatif dapat memberikan pemahaman bagi peserta didik tentang pendidikan seks sejak usia dini dan dapat mencegah perilaku yang merugikan bagi peserta didik dan lingkungan sekitarnya.

Evaluasi terhadap peserta didik berupa penyebaran angket post test diberikan kepada 86 peserta didik SMP Swastika Kapal tentang pendalaman materi Pendidikan Seks, hasil yang dicapai yaitu siswa 
memahami materi Pendidikan Seks sejak usia dini baik melalui paparan dari guru BK dan melihat media BK secara langsung yang dibuat secara kreatif.

\section{Simpulan dan Saran}

Hasil pelatihan dapat disimpulkan bahwa a) kegiatan pelatihan sangat bermanfaat bagi guru BK mengingat ketersediaan media BK di sekolah sangat minim, b) materi yang disampaikan menambah wawasan guru BK dan peserta didik yang menerima materi memiliki pengetahuan awal mengenai pendidikan seks sehingga dapat mencegah perilaku yang tidak diinginkan, c) kegiatan yang di awal didukung oleh Sekolah memberikan situasi yang aman dan lancar dalam pelatihan sehingga kegiatan berjalan sesuai rencana, d) penerapan Media BK diharapkan memiliki ragam tema dan ide yang kreatif sehingga program BK di Sekolah berjalan secara efektif.

\section{Daftar Rujukan}

Afrianto, Irawan. 2011. Collaborative Learning System Sebuah Alternatif Konten C-Generation dan Flagship Detiknas. Majalah Ilmiah UNIKOM Vol.8, No. 1 Hal. 69-76. Tersedia Pada: https://jurnal.unikom.ac.id/jurnal/collaborative-learning-system.1e.

Alma, Buchari.2009. Guru Profesional Menguasai Metode dan Terampil Mengajar. Bandung: Alfabeta.

Chomaria, Nurul. 2012. Pendidikan Seks Untuk Anak. Solo : Aqwam

Depdiknas.2002. Pengembangan Sistem Pendidikan Tenaga Kependidikan Abad ke 21 (SPTK-21). Jakarta: Depdiknas.

Geldard, Kathryn. 2010. Konseling Remaja (Intervensi Praktis bagi Remaja Beresiko). Yogyakarta : Pustaka Pelajar

Hadi Pranoto, Nurul Atieka. 2016. Media Gambar untuk Meningkatkan Pengetahuan Karir Siswa di SD Negeri Jeringjing Sungkai Utara. Jurnal Konseling Komprehensif; Vol.3, No.2, Hal163-175.

http://www.kompasiana.com

https://www.jpnn.com/news/miris-62-persen-anak-smp-pernah-berhubungan-intim-21-persen-pernahaborsi. Diakses tanggal 6 Juli 2018.

https://www.bps.go.id/linkTableDinamis/view/id/985. Diakses tanggal 6 Juli 2018.

Kamaluddin, H. 2011. Bimbingan dan Konseling Sekolah. Jurnal Pendidikan dan Kebudayaan, Vol. 17, Nomor 4 4 Hal. 447-454. Tersedia https://jurnaldikbud.kemdikbud.go.id/index.php/jpnk/article/view/40.

Munirah. 2015. Sistem Pendidikan di Indonesia: antara keinginan dan realita. Auladuna, Vol. 2 No. 2 Hal. 233-245. Tersedia Pada: http://journal.uin-alauddin.ac.id/index.php/auladuna/article/view/879.

Nursalim, Mohhamad. 2013. Pengembangan Media Bimbingan dan Konseling. Jakarta : Indeks

Omeri, Nopan. 2015. Pentingnya Pendidikan Karakter dalam Dunia Pendidikan. Manajer Pendidikan, Volume 9, Nomor 3, hlm. 464-468. Tersedia Pada: https://ejournal.unib.ac.id/index.php/manajerpendidikan/article/view/1145/0.

Permendikbud Nomor 111 Tahun 2014 pasal 4 ayat (4)

Pranoto, Hadi. 2018. Media dan Teknologi Informasi dalam Layanan Bimbingan dan Konseling. Lampung; Lemlit UM Metro Press.

Sitorus, Satriana. 2016. http://www.jurnalasia.com/opini/pengaruh-gadget-di-kalangan-pelajar. Diakses tanggal 7 Juli 2018. 
Sarwono, Sarlito Wirawan. 2005. Psikologi Remaja. Jakarta: Rajawali Pers.

Wilson, Nadeak. 1991. Memahami Anak Remaja. Yogyakarta : Kanisius

Yusuf, Syamsu. 2016. Psikologi Perkembangan Anak dan Remaja. Bandung : Remaja Rosdakarya 